7. Clegg R 1980 Activation of milk lipase by serum proteins: possible role in the occurrence of lipolysis in raw bovine milk. J Dairy Res 47:61

8. DiCorleto PE, Zilversmit DB 1975 Lipoprotein lipase activity in bovine aorta. Proc Soc Exp Biol Med 148:1101

9. Dole VP, Meinertz H 1960 Microdetermination of long chain fatty acids in plasma and tissues. J Biol Chem 235:2295

10. Forsyth JS, Ross PE, Bouchier IAB 1983 Bile salts in breast milk. Eur J Pediatr 140:126

11. Fredrikzon B, Hernell O, Blackberg L, Olivecrona T 1978 Bile salt stimulated lipase in human milk: evidence of activity in vivo and of a role in the digestion of milk retinol esters. Pediatr Res 12:1048

12. Freudenberg E 1953 Die Frauenmilchlipase. Karger, Basel.

13. Friend BS, Shahani KM, Long CA, Vaughn LA 1983 The effect of processing and storage on key enzymes, B vitamins and lipids of mature human milk. I. Evaluation of fresh samples and effects of freezing and frozen storage. Pediatr Res 17:61

14. Garza C, Johnson CA, Harrist R, Nichols BL 1982 Effects of methods of collection and storage on nutrients in human milk. Early Hum Dev 6:295

15. Hamosh M 1981 Physiological role of milk lipases. In: Lebenthal E (ed) Textbook of Gastroenterology and Nutrition. Raven Press, New York, p 473

16. Hargreaves $T 1973$ Effect of fatty acids on bilirubin conjugation. Arch Dis Child 48:446

17. Hernell O, Olivecrona T 1974 Human milk lipases. I. Serum-stimulated lipase J Lipid Res 15:367

18. Hernell O, Olivecrona T 1974 Human milk lipases. II. Bile salt stimulated lipase. Biochem Biophys Acta 369:234

19. Hernell O 1975 Human milk lipases. III. Physiological implications of the bile salt stimulated lipase. Eur J Clin Invest 5:267

20. Hernell O, Blackberg L, Olivecrona T 1981 Human milk lipases. In: Lebentha E (ed) Textbook of Gastroenterology and Nutrition. Raven Press, New York, p 347

21. Mehta NR, Jones JB, Hamosh M 1982 Lipases in preterm human milk: ontogeny and physiologic significance. J Pediatr Gastroenterol Nutr 1:317

22. Rapport MA, Alonzo N 1959 Photometric determination of fatty acid ester groups in phospholipids. J Biol Chem 217:193

23. Schwartz DP, Parks OW 1974 The lipids of milk: deterioration. In: Webb BH Johnson AH, Alford JA (eds) Fundamentals of Dairy Chemistry. Avi Publishing Co, Inc, Westport, CT, p 220

24. Sundheim T, Zimmer L, Astrup HN 1983 Induction of milk lipolysis by lipoprotein components of bovine blood serum. J Dairy Sci 66:400

25. Sunshine $P 1980$ Human breast milk-storage and safety considerations. Western J Med 132:61

26. Tarassuk NP, Nickerson TA, Yaguchi M 1964 Lipase action in human milk. Nature 201:298

27. Wardell J, Hill C, D'Souza S 1981 Effect of pasteurization and of freezing and thawing human milk on its triglyceride content. Acta Paediatr Scand 70:467

28. Williamson S, Finucane E, Ellis H, Gamsu H 1978 Effect of heat treatment of human milk on absorption of nitrogen, fat, sodium, calcium and phosphorus by preterm infants. Arch Dis Child 53:555

\title{
The Effect of Calcium Antagonists on Hypoxic Pulmonary Hypertension in the Piglet
}

\author{
PAULO J. DICKSTEIN, OSWALDO TRINDADE, RONALD N. GOLDBERG, AND \\ EDUARDO BANCALARI \\ Division of Nêonatology and Department of Pediatrics, University of Miami School of Medicine, Miami, \\ Florida 33101
}

\begin{abstract}
Cardiovascular responses to the calcium antagonists verapamil and nifedipine were evaluated in a piglet model of hypoxic pulmonary hypertension. All animals were mechanically ventilated and paralyzed. Cardiac output (CO), pulmonary artery (Ppa) and aortic blood pressure (AoP), pulmonary wedge pressure, right atrial pressure (Pra), and arterial blood gases were measured prior to and after pulmonary hypertension was induced by hypoxia and after administration of calcium-blocking agents. Results were compared to a control group of piglets subjected to a similar period of hypoxia. Verapamil infusion $(0.15 \mathrm{mg} / \mathrm{kg})$ resulted in a rapid decrease in $\overline{\mathrm{Ppa}}, \overline{\mathrm{AoP}}$ and pulmonary vascular resistance $(p<0.05)$ which returned to baseline values by $15 \mathrm{~min}$. Nifedipine $(100 \mu \mathrm{g} /$ $\mathrm{kg}$ ) resulted in a decrease in Ppa at $1 \mathrm{~min}(p<0.05)$ which remained significantly lower than controls throughout the study period. AoP declined precipitously during the same time period $(p<0.01)$. No significant change in Ppa was noted when nifedipine was administered at a dose of $10 \mu \mathrm{g} /$
\end{abstract}

Received August 4, 1983; accepted May 7, 1984

Correspondence may be addressed to Ronald N. Goldberg, M.D., Department of Pediatrics (R-131), University of Miami School of Medicine, P.O. Box 016960, Miami. FL 33101

This work was supported in part by National Institutes of Health Grants 1RO1 HD14940-03 and 5RO1 HL25023-03, March of Dimes Research Grant 6-303, and University of Miami Project: New Born. kg. For the most part, these drugs have a transient vasodilatory action on pulmonary as well as systemic circulation in this animal model; however, they might in higher doses be associated with significant systemic hypotension. For this reason, the use of these drugs in the treatment of hypoxic pulmonary hypertension in the neonate should be approached with caution. (Pediatr Res 18:1262-1265, 1984)

\section{Abbreviations}

AoP, aortic blood pressure

$\mathrm{CO}$, cardiac output

Ppa, pulmonary artery pressure

Ppaw, pulmonary wedge 'ressure

Pra, right atrial pressure

PVR, pulmonary vasculat .esistance

SVR, systemic vascular resistance

Pulmonary hypertension with secondary right to left shunting through the foramen ovale and/or ductus arteriosus is a common problem in the neonatal period. It has been associated with hyaline membrane disease (9), transient tachypnea of the newborn (4), meconium aspiration (8), fetal hypoxia (20, 22), and 
neonatal pneumonia (10). These conditions are similar in that hypoxia, which is a significant component of each disorder, may initiate or contribute to the development of pulmonary hypertension. Therapies employed to treat the resulting pulmonary hypertension have included tolazoline and mechanical hyperventilation with induction of alkalosis. The latter treatment has been shown to reduce pulmonary artery pressure in neonates (18). Despite these approaches, in many cases the pulmonary hypertension and hypoxemia persist, resulting in a high mortality.

It has been postulated that hypoxia results in pulmonary vasoconstriction secondary to smooth muscle membrane depolarization and transmembrane influx of extracellular calcium (2, $3,6,14)$. It has also been speculated that alkalosis secondary to hyperventilation may reduce hypoxia-induced pulmonary vasoconstriction by decreasing extracellular ionized calcium $(1,19)$. In view of these hypotheses, the present study was undertaken to evaluate the effect of the calcium antagonists, verapamil and nifedipine, on hypoxic pulmonary hypertension in a piglet model.

\section{MATERIALS AND METHODS}

Piglets ages 6 to 30 days were anesthetized with $30 \mathrm{mg} / \mathrm{kg}$ of pentobarbital given intraperitoneally. A femoral artery and vein were cannulated and used for AoP measurement, blood sampling, and drug infusions. The left external jugular vein was cannulated and the catheter was advanced into the right atrium for measurement of pressure and injection of iced saline which was used for measurement of cardiac output. A 5F Swan-Ganz thermodilution catheter was introduced into the right external jugular vein and advanced under fluoroscopy into the left pulmonary artery. $\mathrm{CO}$ was measured by thermodilution using a cardiac output computer (9510-A, Edwards Laboratory, Santa Ana, CA) and corrected for weight. This catheter was also used for measurement of Ppa and Ppaw. Heparinized normal saline (10 units/cc) was infused continuously through the pulmonary artery catheter. Vascular pressures were measured with pressure transducers (model P23; Gould-Statham Instruments, Hato Rey, PR) and recorded on a multichannel recorder (model 5 polygraph, S2-925T25; Grass Instrument, Quincy, MA).

Tracheostomy was performed and the piglets were ventilated with a Sechrist ventilator (model IV-100 B infant ventilator; Sechrist Industries, Anaheim, CA). The ventilator was set at a peak inflation pressure of $12 \mathrm{~cm} \mathrm{H}_{2} \mathrm{O}$, end expiratory pressure of $2 \mathrm{~cm} \mathrm{H}_{2} \mathrm{O}$, inspiratory time of $0.5 \mathrm{~s}$, a respiratory rate of $35 /$ min, and an $\mathrm{FiO}_{2}$ of 0.21 . Rate and peak inspiratory pressure were adjusted to maintain the $\mathrm{PaCO}_{2}$ between 35 and $40 \mathrm{~mm} \mathrm{Hg}$.

Arterial blood gases were measured prior to and after hypoxia was induced and 30 min after calcium antagonists were given (pH/Blood Gas Analyzer 113, Instrument Laboratory Inc., Lexington, MA). Rectal temperature was recorded continuously (Yellow Springs Instrument Co., Yellow Springs, $\mathrm{OH}$ ), and maintained at $38.0^{\circ} \mathrm{C}$ by means of a radiant warmer.

Arterial blood and pulmonary artery pressures were measured continuously. Cardiac ouput and pulmonary wedge and right atrial pressures were measured prior to and after hypoxia, and at 5,15 , and $30 \mathrm{~min}$ after verapamil or nifedipine was given. PVR was calculated using the formula: $(\overline{\mathrm{Ppa}}-\mathrm{Ppaw}) / \mathrm{CO} / \mathrm{kg}$ SVR calculated using the formula: $(\overline{\mathrm{AoP}}-\mathrm{Pra}) / \mathrm{CO} / \mathrm{kg}$. The animals were paralyzed with pancuronium bromide using an initial intravenous dose of $0.1 \mathrm{mg} / \mathrm{kg}$ followed by an infusion of $0.3 \mathrm{mg} / \mathrm{kg} /$ h. After $30 \mathrm{~min}$, baseline cardiovascular measurements and arterial blood gases were obtained. The $\mathrm{FiO}_{2}$ was decreased to $0.10-0.14$ to attain $\mathrm{a} \mathrm{PaO}_{2}<50 \mathrm{~mm} \mathrm{Hg}$.

Measurements were repeated after $30 \mathrm{~min}$. The animals were then allowed to stabilize for an additional $30 \mathrm{~min}$ before baseline hypoxia measurements were made.

After these measurements, nine piglets ( $\bar{x} \pm \mathrm{SD}$; weight, 3302 $\pm 1562 \mathrm{~g}$; age, $18 \pm 6$ days) received verapamil $\mathrm{HCl}(\mathrm{Knoll}$ Pharmaceutical Co., Whippany, NJ) at $0.15 \mathrm{mg} / \mathrm{kg}$ infused into the right atrium over $2 \mathrm{~min}$ while $\mathrm{AoP}$ and Ppa were measured continuously. Six piglets (weight, $4378 \pm 699 \mathrm{~g}$; age, $19 \pm 4$ days) received nifedipine, three receiving a dose of $10 \mu \mathrm{g} / \mathrm{kg}$ and three a dose of $100 \mu \mathrm{g} / \mathrm{kg}$. Four piglets (weight, $3596 \pm 1284 \mathrm{~g}$; age, $17 \pm 10$ days) did not receive any drug and comprised the control group.

Nifedipine (Pfizer Pharmaceuticals, New York) was prepared $2 \mathrm{~h}$ prior to the experiment by dissolving the agent in $95 \%$ ethanol and water, and combining the solutions with polyethylene glycol. The solution was protected from light until infused.

Comparisons between the mean value before and after hypoxia, and drug infusion were performed using the paired $t$ test. Per cent change from hypoxic baseline was compared at $1,5,15$, and $30 \mathrm{~min}$ post-drug infusion between treatment and control animals by two sample $t$ test. Results are expressed as mean \pm $\mathrm{SD}$.

\section{RESULTS}

Hypoxia induced significant increases in mean Ppa (16.0 \pm 6.3 to $28.0 \pm 6.2 \mathrm{~mm} \mathrm{Hg} ; p<0.001), \mathrm{PVR}(59.1 \pm 34.0$ to 112.2 $\pm 39.8 \mathrm{~mm} \mathrm{Hg} / \mathrm{liter} / \mathrm{min} / \mathrm{kg} ; p<0.001)$, and mean AoP (101.3 \pm 15.9 to $113.0 \pm 13.4 \mathrm{~mm} \mathrm{Hg} ; p<0.002$ ). The following comparisons relate per cent change from hypoxic baseline to time post-calcium antagonist administration with comparable time periods in the control animals.

Verapamil administration was associated with a decrease in $\overline{\mathrm{Ppa}}$ and $\overline{\mathrm{AoP}}$ at $1(p<0.01)$ and $5 \mathrm{~min}(p<0.05)$ postinfusion (Fig. 1). By 15 min, these differences had disappeared and Ppa

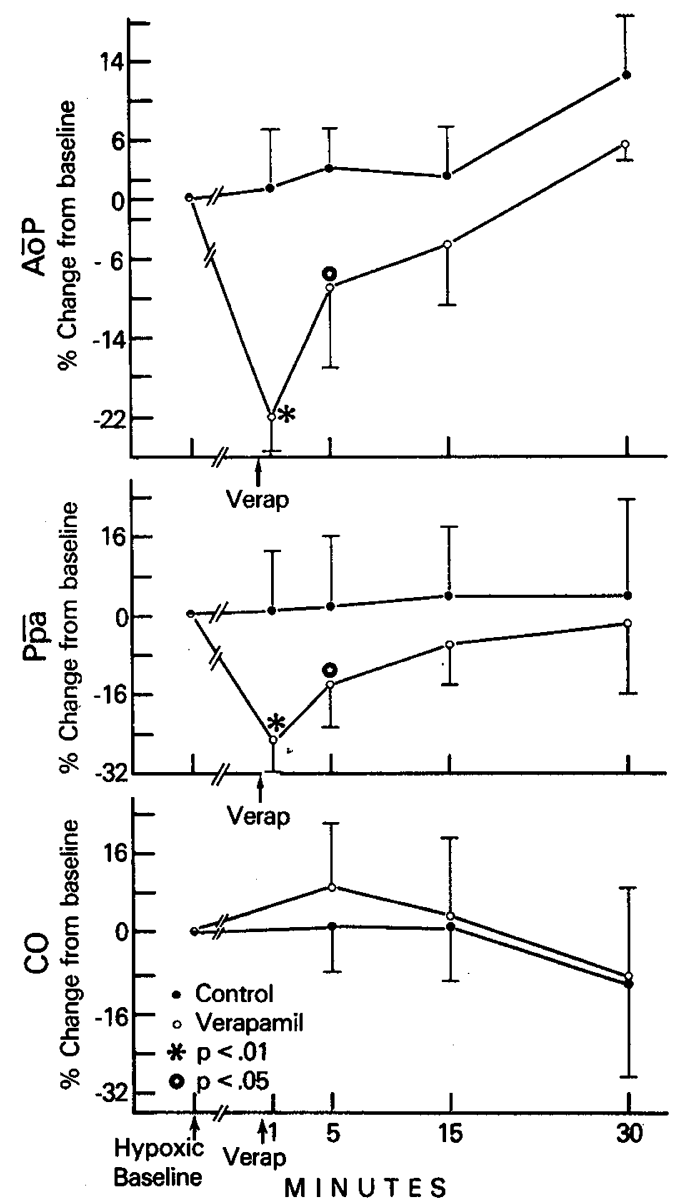

Fig. 1. Mean arterial and pulmonary artery pressure measurements, and cardiac output during hypoxia and after verapamil infusion. The time scale represents time after verapamil administration. Values are expressed as $\bar{x}( \pm \mathrm{SD})$ per cent change from hypoxic baseline $(n=9)$. Significance refers to differences from control animals. 
approximated hypoxic baseline. PVR and SVR were also significantly decreased by $5 \mathrm{~min}(p<0.05)$, but were similar to baseline by $15 \mathrm{~min}$. Cardiac output increased at $5 \mathrm{~min}$ but was not different from control animals.

Nifedipine $(10 \mu \mathrm{g} / \mathrm{kg})$ did not result in a significant drop in $\overline{\mathrm{Ppa}}$ (Fig. 2). However, piglets receiving $100 \mu \mathrm{g} / \mathrm{kg}$ of nifedipine displayed a significant decrease in $\overline{\mathrm{Ppa}}(p<0.05)$ which was different from hypoxic baseline throughout the monitored period. PVR and SVR were significantly decreased at $5 \mathrm{~min}(p<$ $0.05)$. Nifedipine-treated animals displayed progressive deterioration over the study period reflected by a significant decline in $\overline{\text { AoP }}(p<0.01)$ in all animals. Changes in acid-base status were not different from control animals irrespective of drug or dosage.

The ratio of PVR to SVR (Fig. 3) shows no statistically significant change with verapamil or nifedipine $(10 \mu \mathrm{g} / \mathrm{kg})$. This finding indicates that the action of these drugs was nonspecific in that they cause a decrease in systemic as well as pulmonary artery pressure. There was a significant increase in this ratio when a dose of $100 \mu \mathrm{g} / \mathrm{kg}$ of nifedipine was infused $(p<0.01)$. This was related to a more pronounced decrease in SVR compared to PVR.

Four piglets received multiple doses of verapamil $(0.15 \mathrm{mg} / \mathrm{kg}$ per dose at $10-\mathrm{min}$ intervals). The mean total dose used was 0.41 $\mathrm{mg} / \mathrm{kg}$ (range, $0.30-0.60 \mathrm{mg}$ ). The same patterns of response noted in Figure 1 were observed in all animals for each dose. Two additional animals received verapamil as an infusion. One of these received a dose of $0.01 \mathrm{mg} / \mathrm{kg} / \mathrm{min}$ for $30 \mathrm{~min}$. Mean blood pressure decreased from 41 to $37 \mathrm{~mm} \mathrm{Hg}$ and Ppa fell

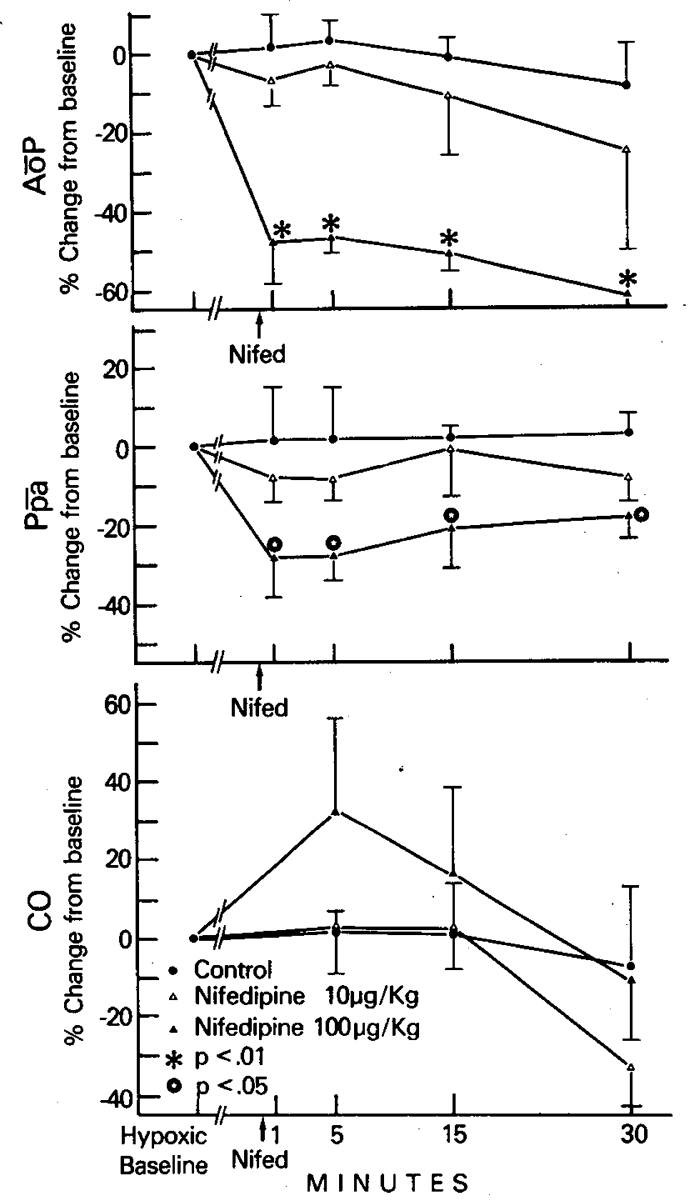

Fig. 2. Mean arterial and pulmonary artery pressure measurements, and cardiac output during hypoxia and after nifedipine infusion. The time scale represents time after nifedipine administration. Values are expressed as $\bar{x}( \pm \mathrm{SD})$ per cent change from hypoxic baseline. Significance refers to differences from control animals. Each study group is comprised of three animals.

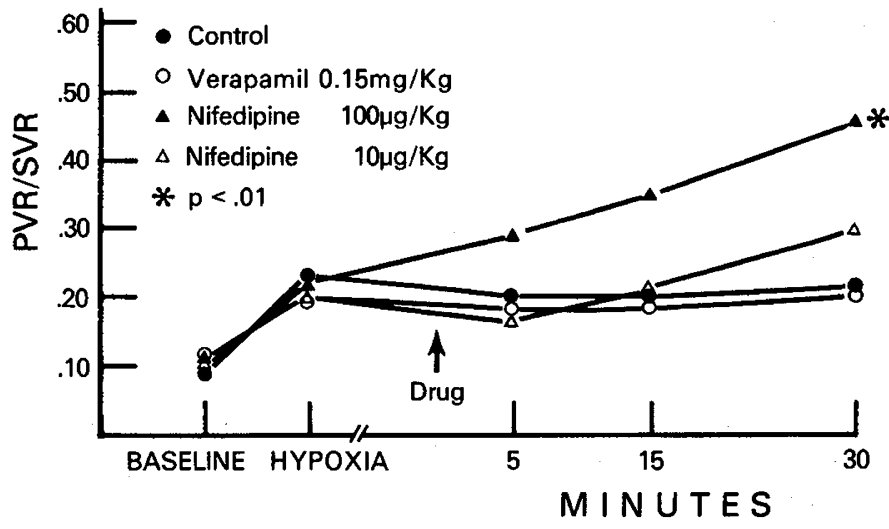

Fig. 3. Ratio of PVR to SVR during hypoxia and after drug administration. The ratio at $30 \mathrm{~min}$ in the nifedipine $100-\mu \mathrm{g}$ group was significantly greater $(p<0.01)$ than the control group.

from 36 to $31 \mathrm{~mm} \mathrm{Hg}$. The remaining piglet received incremental doses of verapamil beginning at $0.001 \mathrm{mg} / \mathrm{kg} / \mathrm{min}$ increasing to $0.015 \mathrm{mg} / \mathrm{kg} / \mathrm{min}$ at which point the AoP declined from 92 to $69 \mathrm{~mm} \mathrm{Hg}$ and the Ppa remained essentially unchanged.

One animal received a total of $40 \mu \mathrm{g} / \mathrm{kg}$ of nifedipine $(10,10$, and $20 \mu \mathrm{g} / \mathrm{kg}$ infusions at $10-\mathrm{min}$ intervals). This resulted in a fall in AoP of $48 \mathrm{~mm} \mathrm{Hg}$ and decrease in Ppa of $3 \mathrm{~mm} \mathrm{Hg}$.

\section{DISCUSSION}

The exact mechanism by which hypoxia induces pulmonary hypertension is unknown. It has been suggested that pulmonary vasoconstriction in the presence of hypoxia might result from membrane depolarization and transmembrane influx of extracellular calcium, or a transmitter-induced release of calcium from an intracellular pool $(3,16)$. These postulations have led to the suggestion that the pressor response to hypoxia may be inhibited by agents that reduce or block calcium entry across the cell membrane (16). In support of this theory, investigators have demonstrated that pulmonary vasoconstriction secondary to alveolar hypoxia is inhibited by verapamil, a calcium antagonist $(16,17)$. Calcium antagonists probably act in this situation by not only reducing membrane permeability to calcium, but also by depressing the rate at which intracellular stores of calcium are replenished from extracellular sources $(2,3,6,7,14,23)$.

Calcium antagonists have been used with varying success to treat adults who have primary pulmonary hypertension $(5,13$, 24). In addition, patients with chronic airflow obstruction and acute respiratory failure with severe pulmonary hypertension. secondary to hypoxic vasoconstriction have responded favorably to calcium antagonists $(12,13,21)$.

Pulmonary hypertension accompanies a number of neonatal disorders. Frequently, the precipitating mechanism for pulmonary hypertension in these disorders is hypoxia before, at, or soon after birth. The present study attempted to look at treatment of hypoxia-induced pulmonary hypertension in a young animal model to ascertain if therapy with calcium antagonists could ameliorate pulmonary hypertension. However, caution must be exercised in extrapolating the results of these animal data to the human neonate in that pulmonary hypertension secondary to hypoxia was produced in normal lungs, and that right-to-left shunting through the foramen ovale and ductus arteriosus have not been demonstrated in similar age piglets. Although shunts were not ruled out in the subjects of this study, we have recorded cardiac output simultaneously using a Swan-Ganz catheter placed in the pulmonary artery and a thermodilution catheter placed in the descending aorta in 26 piglets ages 6 to 28 days with hypoxic pulmonary hypertension without demonstrating a shunt. While these data emphasize the differences in physiology between this species and the human neonate, in whom shunts 
are common, they suggest that the cardiac output data are reliable.

The present data reveal that while there is an early drop in Ppa in animals treated with verapamil and nifedipine $(100 \mu \mathrm{g} /$ $\mathrm{kg}$ ), the response is short-lived. In addition, the response is nonspecific as reflected by the absence of a significant change in the PVR/SVR ratio for verapamil and nifedipine $(10 \mu \mathrm{g} / \mathrm{kg})$. The higher dose of nifedipine resulted in an increase in PVR/ SVR, indicating a more pronounced decrease in SVR in relation to PVR.

The initial dose of nifedipine $(100 \mu \mathrm{g} / \mathrm{kg})$ used in this experiment was based on work done in experimental animals (15). This dose, however, resulted in marked clinical deterioration manifested by significant decline in arterial blood pressure. Consequently, a lower dose $(10 \mu \mathrm{g} / \mathrm{kg})$ was used. Furthermore, the action of both verapamil and nifedipine seems extremely shortlived. The explanation of this is unclear in view of the noted half-lives of verapamil ( 3 to $7 \mathrm{~h}$ ) and nifedipine $(5 \mathrm{~h})$ in humans (11). Plasma levels of these drugs were not obtained in the present study and, therefore, it is not clear whether the short duration of action could have been due to a short half-life in these animals. Although the number of animals treated with multiple doses of these drugs is limited, these preliminary findings do not support the benefit of multiple doses. However, the use of continuous infusions of these drugs combined with the use of a peripheral pressor agent may be beneficial.

In conclusion, these drugs have for the most part a transient, vasodilatory action on pulmonary as well as systemic circulation. In addition, they may result in significant clinical deterioration. For these reasons, it is unlikely that they could play a significant role in reducing hypoxic pulmonary hypertension in the neonate.

Acknowledgments. The authors wish to express their thanks to Ralph N. Cicalese for his excellent technical assistance, to Dr. George B. Bikhazi and Ignatius Leung for their assistance, to Leticia Hernandez and Patricia Ayon de Lujan for their secretarial support, and to Dr. Mary Jane Jesse for her critical review of this manuscript.

\section{REFERENCES}

1. Anderson RGG 1972 Cyclic AMP and calcium ions in mechanical and metabolic responses of smooth muscles: influence of some hormones and drugs. Acta Physiol Scand Suppl 382:1
2. Bergofsky EH, Holtzman S 1967 A study of the mechanisms involved in the pulmonary arterial pressor response to hypoxia. Circ Res 20:506

3. Bohr DE 1973 Vascular smooth muscle update. Circ Res 32:665

4. Bucciarelli RL, Egan EA, Gessner IH, Eitzman DV 1976 Persistence of fetal cardiopulmonary circulation: one manifestation of transient tachypnea of the newborn. Pediatrics 58:192

5. Camerini E, Alberti E, Klugmann S, Salvi A 1980 Primary pulmonary hypertension: effects of nifedipine. $\mathrm{Br}$ Heart J 44:352

6. Detar R, Gellai M 1971 Oxygen and isolated vascular smooth muscle from the main pulmonary artery of the rabbit. Am J Physiol 221:1791

7. Deth $\mathrm{R}$, Van Breeman $\mathrm{C} 1974$ Relative contribution of $\mathrm{Ca}^{++}$influx and cellular $\mathrm{Ca}^{++}$release during drug induced activation of the rabbit aorta. Pfluegers Arch 348:13

8. Fox WW, Grewitz MW, Dinwiddie R, Drummond WH, Peckham GJ 1977 Pulmonary hypertension in the perinatal aspiration syndromes. Pediatrics 59:205

9. Goetzman BW, Sunshine P, Johnson JD, Wennberg RP, Hackel A, Merten DF, Bartoletti AL, Silverman NH 1976 Neonatal hypoxia and pulmonary vasospasm: response to tolazoline. J Pediatr 89:617

10. Hageman JR, Adams MA, Gardner TH 1983 Persistent pulmonary hypertension in the newborn with early-onset neonatal infection. Pediatr Res 17:315A (abstr)

11. Henry PD 1980 Comparative pharmacology of calcium antagonists: nifedipine, verapamil and diltiazem. Am J Cardiol 46:1047

12. Joshi PL, Dalal JJ, Ruttley MSJ, Sheridan DJ, Henderson AH 1981 Nifedipine and left ventricular function in beta-blocked patients. Br Heart J 45:457

13. Landmark K, Refsum AM, Simonsen S, Storstein O 1978 Verapamil and pulmonary hypertension. Acta Med Scand 204:299

14. Lloyd TC Jr 1970 Responses to hypoxia of pulmonary arterial strips in non aqueous baths. J Appl Physiol 28:566

15. Malo PE, Wasserman MA, Griffin RL 1982 Effects of intravenous and aerosol nifedipine on prostaglandin $F_{2}$ and histamine-induced bronchoconstriction in anesthetized dogs. J Pharmacol Exp Ther 221:410

16. McMurtry IF, Davidson AB, Reeves JT, Grover RF 1976 Inhibition of hypoxic pulmonary vasoconstriction by calcium antagonists in isolated rat lung. Circ Res 38:99

17. Naeije R, Melot C, Mols P, Hallemans R 1982 Effects of vasodilators on hypoxic pulmonary vasoconstriction in normal man. Chest $82: 404$

18. Peckham GJ, Fox WW 1978 Physiologic factors affecting pulmonary artery pressure in infants with persistent pulmonary hypertension. J Pediatr 93:1005

19. Romero PJ, Whittan R 1971 The control by internal calcium of membrane permeability to calcium and potassium. J Physiol (Lond) 214:481

20. Rudolph AM, Yuan S 1966 Response of the pulmonary vasculature to hypoxia and $\mathrm{H}^{+}$ion concentration changes. $\mathrm{J}$ Clin Invest 45:399

21. Simonneau G, Escourrou P, Duroux P, Lockhart A 1981 Inhibition of hypoxic pulmonary vasoconstriction by nifedipine. N Engl J Med 304:1582

22. Soifer SJ, Kaslow D, Heymann MA 1983 Prolonged intrauterine hypoxia produces pulmonary hypertension in the newborn lamb. Pediatr Res 17:336A (abstr)

23. Van Breeman C, Farinas BR, Gerba P, McNaughton ED 1972 Excitationcontraction coupling in rabbit aorta studied by lanthanum method for measuring cellular calcium influx. Circ Res 30:44

24. Wood BA, Tortoledo F, Luck JC, Fennell WH 1982 Rapid attenuation of response to nefedipine in primary pulmonary hypertension. Chest 82:793 